\title{
Zoonotic cutaneous leishmaniasis and Leishmania infection among Meriones shawi population in Setif Province, Algeria
}

\author{
AMINA FELLAHI ${ }^{1, \bullet}$, NACER DJIRAR $^{1}$, ABDELKADER CHERIEF $^{2}$, ABDELKRIM BOUDRISSA $^{3}$, \\ NAOUEL EDDAIKRA ${ }^{3}$ \\ ${ }^{1}$ Laboratory of Improvement and Development of Plant and Animal Production, University of Ferhat Abbas. El Bez, Sétif 19000, Algeria. \\ Tel.:+213-658-101010, `email: amina.fellahi@univ-setif.dz \\ ${ }^{2}$ Laboratory of Agronomic Sciences, Faculty of Sciences, University of M'Sila. BP 166, 28000, Algeria \\ ${ }^{3}$ Laboratory of Eco-epidemiology Parasitic Population Genetics, Pasteur Institute of Algiers. Route du petit Staouèli, Dély Ibrahim, Algiers, Algeria
}

Manuscript received: 8 February 2021. Revision accepted: 2 June 2021.

\begin{abstract}
Fellahi A, Djirar N, Cherief A, Boudrissa A, Eddaikra N. 2021. Zoonotic cutaneous leishmaniasis and Leishmania infection among Meriones shawi population in Setif Province, Algeria. Biodiversitas 22: 2547-2554. Zoonotic cutaneous leishmaniasis (ZCL) is the most endemic disease in Algeria. Leishmania major is the causative agent, and Gerbils Meriones shawi and Psammomys obesus are the main reservoir hosts. The Province of Setif in Algeria has become a very active focus for this zoonosis. Our study was carried out from January 2017 until January 2019 in ten representative stations of the study area, with an aim to identify the association between zoonosis and reservoir host species. Eighty-six (86) specimens of $M$. shawi and three (3) specimens of $P$. obesus were captured and determined. Superficial lesions were subjected to Giemsa stained smears. In addition, Livers and spleens were tested for Leishmania DNA using ITS1 PCR. The results showed the presence of $M$. shawi in almost all communities of Setif Province and the highest population with 50 specimens $(58.13 \%)$ was in the center and south. The microscopic and molecular detection of Leishmania showed high infestation in most specimens of Meriones (32/86) with a rate of $37.20 \%$, however, no infestation in Psammomys has been detected. The PCA results showed a negative association between rainfall and ZCL cases; however, positive association was found between temperature and the human CL cases. Also, positive association was demonstrated between ZCL in south and center of Setif Province and Meriones captured. Our finding, confirm that M. shawi is the principal reservoir host (76.78\%) of the ZCL in Setif Province, since $P$. obesus was nearly absent $(2.67 \%)$.
\end{abstract}

Keywords: Meriones shawi, reservoir host, rodent, zoonotic cutaneous leishmaniasis

\section{INTRODUCTION}

Zoonotic Cutaneous leishmaniasis (ZCL) is one of the most important parasitic diseases of mammals and humans (Barkati et al. 2019; Tabbabi 2019). This form represents $75 \%$ of all leishmaniasis (de Souza et al. 2015). Leishmania major (L. major) an obligate intracellular parasite are known to be the causative agent (Aoun and Bouratbine 2014; Chaara et al. 2014). The vector is Phlebotomus papatasi (Izri et al. 1992). The main mammalian reservoirs of the parasite $L$. major are specifically wild rodents of Gerbillidae family, including Meriones shawi (M. shawi) and Psammomys obesus ( $P$. obesus), which are closely associated with humans (Belazzoug 1986; Reithinger et al. 2007; Aoun and Bouratbine 2014; Akhoundi et al. 2016). This rodent species has a significant role in the transmission of disease (Bernard 1977; Teka et al. 2002; Derbali et al. 2012; Samy et al. 2016). The ZCL disease is a major public health problem, that about 10,000 new cases are reported every year, and about two-thirds of cases occur in Afghanistan, Colombia, Syria, Brazil, Iran, and Algeria (Alvar et al. 2012; Mohamedbeigi et al. 2019; WHO 2019). It is difficult to treat because no vaccine is yet available (Seid et al. 2014). This form of leishmaniases is endemic in many areas of the tropics and subtropics and the Mediterranean basin, spanning generally more than 98 countries (Reithinger et al. 2007; Alvar et al. 2012; WHO 2019). In fact, this means that there are about 350 million people at risk of zoonotic CL that has existed for many years and caused by $L$. major, the most common parasite found in northern Africa, where the incidence rate of ZCL largely exceeds thousands of cases per year (Pratlong et al. 2009; Alvar et al. 2012; Eddaikra et al. 2018; WHO 2019).

Algeria is considered one of the ten most affected countries of cutaneous leishmaniasis globally, and it represents the second focus, after Afghanistan, with 10847 cases in 2018 (Eddaikra et al. 2018; WHO 2019). Thus, Zoonotic Cutaneous leishmaniasis is endemo-epidemic in arid and semi-arid Algeria areas. The first identification of the parasite was in the Province of Biskra in 1910 (Sergent et al. 1921). In recent years, there has been an increase in the prevalence of the LCZ and an extension to the north of the country (Harrat et al. 1996; Alvar 2012). The disease is spreading rapidly and creating new and important outbreaks such as those in M'Sila, Batna, Bechar, El Oued, Ghardaia, Bordj Bou Arreridj, Djelfa, Saida, and Setif (Belazzoug 1982; Boudrissa et al. 2012; Benelmouffok et al. 2017). Our interest is particularly focused on the Province of Setif. This province is bordering the epidemiological foci of ZCL, especially those of Hodna which is considered a permanent focus. Until now, no eco- 
epidemiological work on ZCL has been done; based on this, an intervention study of the reservoir host is needed to better understand the prevalence of ZCL in Setif. Due to the importance of these Gerbils in the maintenance of $L$. major, This study aimed to identify the relationship between $M$. shawi and ZCL prevalence in Setif area to establish a preventive and successful control strategy based on reservoir host in endemic periods.

\section{MATERIALS AND METHODS}

\section{Study area description}

Setif Province is situated on a high plain (North East of Algeria), with an estimated area of $6550 \mathrm{~km} 2$, an altitude of $1100 \mathrm{~m}$, and approximately 1,489,979 inhabitants. It is distant from the capital; Algiers, by $300 \mathrm{~km}$. To the north, it borders Bejaia and Jijel, to the south; it borders M'Sila and Batna, to the east, Mila and to the west, Bordj BouArriridj. The relief of Setif is divided into three main areas: northern mountainous zone, central plains spacing, and southern low zone (composed of desert chain). The Setif Province enjoys a semi-arid continental climate with wet and cold winter and hot and dry summer (Figure 1).

\section{Retrospective study of cutaneous Leishmaniasis in Setif}

We conducted a retrospective study on the incidence of cutaneous leishmaniasis in our study area (Departement of Sétif), over 11 year period from 2008 to 2018. All data were provided by the Directorate of Health and Population (DSP: Direction de la santé et de la population) from the Annual Epidemiologic Data collection (REM: Relevé épidemiologique mensuel). Among these data: the number of cases of CL recorded per year, and the distribution of cases by age and gender. Positive cases of ZCL were reported and recorded by health facilities in the study areas during the 2008-2018 period.

\section{Climatic data}

To determine the links between the frequency of ZCL and the climatic factors, we collected the temperature and rainfall data recorded during 2017 and 2018, from the National Office of Meteorology (ONM) of Setif in the Setif International Airport (World Meteorological Organization), which were registered daily.

\section{Rodent trapping and capture}

Site selection

Two criteria were used to choose the target communities for the study of the relationship between zoonotic cutaneous leishmaniasis and the reservoir host Meriones shawi (Figure 1): The first was based on the number of ZCL cases registered and notified in Setif Province (Figure 2). The CL clinical data used in this study were taken from the Directorate of Health and Population (Direction de la Santé et de la Population; DSP-Setif ) to find the pattern of cutaneous leishmaniasis and theredistribution points. Villages with more positive ZCL cases during 2017 and 2018 were selected as best sites for the study (critical areas for transmission of ZCL); and the second was related to rodents distribution, their ecological niches, and active burrows number, established based on field observations in search for activity indices and reports from IPVCT-DSA (Directorate of Agricultural Services; DSA -Setif). Besides, related to infestations in agricultural areas by $M$. shawi. The target stations are chosen for the catch of rodents. The coordinates of the selected sites were recorded by GPS (Table 1).

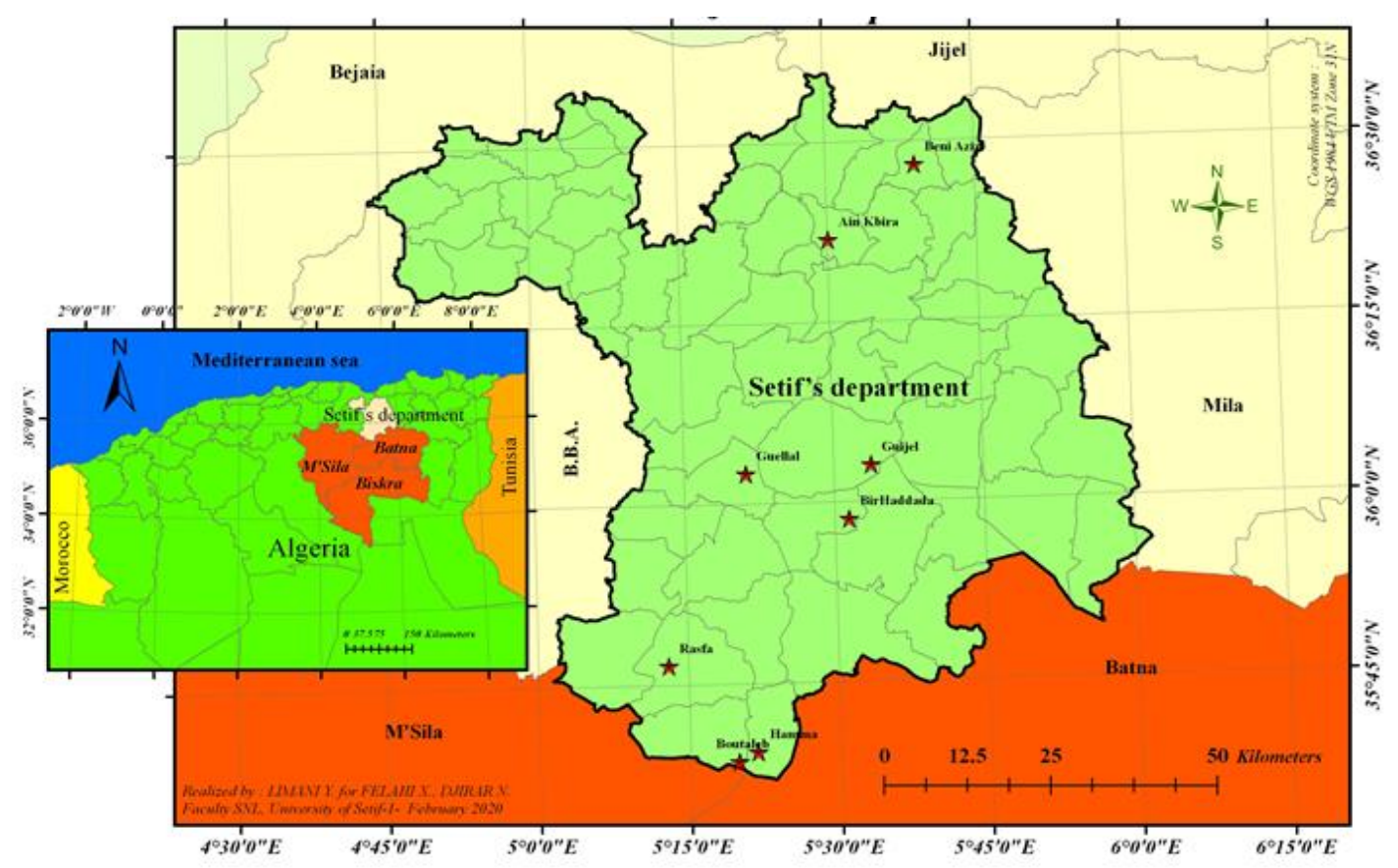

Figure 1. Location of Setif Province in Algeria indicating the sampling sites of rodents and its borders with epidemiological foci of ZCL 
Table 1. Coordinates of rodents trapping sites, Setif Province, Algeria

\begin{tabular}{|c|c|c|c|}
\hline Site & Latitude & Longitude & Alt. (m) \\
\hline Beni Aziz & $36^{\circ} 28^{\prime} 0^{\prime \prime} \mathrm{N}$ & $5^{\circ} 39^{\prime} 0^{\prime \prime} \mathrm{E}$ & 775 \\
\hline Ain Kbira & $36^{\circ} 21^{\prime} 53^{\prime \prime} \mathrm{N}$ & $5^{\circ} 30^{\prime} 7^{\prime \prime} \mathrm{E}$ & 1024 \\
\hline Bougaa & $36^{\circ} 19^{\prime} 57^{\prime \prime} \mathrm{N}$ & $5^{\circ} 05^{\prime} 19^{\prime \prime} \mathrm{E}$ & 1050 \\
\hline Guijel & $36^{\circ} 3{ }^{\prime} 3.81^{\prime \prime} \mathrm{N}$ & $5^{\circ} 33^{\prime} 47.33^{\prime \prime} \mathrm{E}$ & 969 \\
\hline Guellal & $36^{\circ} 2{ }^{\prime} 31.16^{\prime \prime} \mathrm{N}$ & $5^{\circ} 21$ '14.69'"E & 910 \\
\hline Bir Haddada & $35^{\circ} 58^{\prime} 34.63^{\prime \prime} \mathrm{N}$ & $5^{\circ} 31^{\prime} 28.04 ’ \mathrm{E}$ & 951 \\
\hline El Eulma & $36^{\circ} 9^{\prime} 37.082^{\prime \prime} \mathrm{N}$ & $5^{\circ} 41^{\prime} 54.232$ ”'E & 959 \\
\hline Rasfa & $35^{\circ} 46^{\prime} 37.86^{\prime \prime} \mathrm{N}$ & $5^{\circ} 13^{\prime} 1.55^{\prime \prime} \mathrm{E}$ & 833 \\
\hline Hamma & $35^{\circ} 39^{\prime} 18.04 ” \mathrm{~N}$ & $5^{\circ} 21^{\prime} 45.61^{\prime \prime} \mathrm{E}$ & 833 \\
\hline Boutaleb & $35^{\circ} 38^{\prime} 31.45^{\prime \prime} \mathrm{N}$ & $5^{\circ} 19^{\prime} 51.74 ” \mathrm{E}$ & 795 \\
\hline
\end{tabular}

\section{Ethics statement}

All experiments were carried out in compliance with the Federation of European Laboratory Animal ScienceAssociations (FELASA) guidelines and approved by the Ethical Committee of the Pasteur Institute in Algiers.

\section{Rodents catching and identification}

The rodent catching period was from January 2017 to January 2019 (two years), using two types of traps, Sherman and wire Mesh cages. Eight (8) traps were placed once time per month in each of the ten selected sites in the afternoon and collected the morning of the following day, which makes (80) traps in total. The aerated wire-mesh traps have been equipped with food (dates) to limit the stress of the trapped animals before transferring them to the laboratory. Trapping sessions were conducted in winter, spring, summer and autumn. The collected rodent specimens were brought to the Laboratory of Institute Pasteur of Algeria (IPA)/ Branch of M'sila. Each specimen was killed with ether, and then identified according to the determination keys described by Bernard 1977 and Etemad 1978. Four external measurements were taken from each specimen in $\mathrm{mm}$ by using a digital micrometer caliper (Fisherbrand): head and body length (HBL), ear length (EL), tail length (TL), and hindfoot length (HFL). The animals were also weighed (gr).

\section{Smear of lesions}

CL lesions were found mainly on rodents ears and noses. All superficial lesions were subjected to dermal smears stained with MGG May Grunewald Giemsa. Slides were MGG stained for microscopic observation of Leishmania amastigotes (Gx1000).

\section{DNA extraction and electrophoresis}

Spleen and liver samples were obtained from all rodent specimens. After collection, the specimens were stored in $70 \%$ ethanol until DNA extraction. To perform Phenol/chloroform-based DNA extraction method: $10 \mathrm{mg}$ of spleen tissue was homogenized in $200 \mu \mathrm{L}$ of lysis Solution (100 mM NaCl, $10 \mathrm{mM}$ Tris-HCl, and 0.5\% SDS, $\mathrm{pH}$ 8). To digest the protein, $20 \mu \mathrm{L}$ proteinase $\mathrm{K}(20$ $\mathrm{mg} / \mathrm{mL}$ ) was added, and then, the samples were incubated at $56^{\circ} \mathrm{C}$ for $12 \mathrm{~h}$. A phenol chloroform extraction was performed (Sidorova et al. 2012). DNA was detected after amplification of the ribosomal internal transcribed spacer 1 (ITS1 F: CTGGATCATTTTCCGATG; ITS1 R: TGATACCACTTATCGCACTTA) was monitored as described by Schönian et al. (2003), using the primers LITSR and L5.8S. The PCR mix $(25 \mu \mathrm{L})$ contained $2.5 \mu \mathrm{L}$ of DNA, 10x buffer, $300 \mu \mathrm{M} \mathrm{MgCl2,} 200 \mu \mathrm{MdNTP}, 500$ $\mathrm{nM}$ of each primer, and 2 Uof Taq DNA polymerase. PCR amplification products being obtained were separated on a $1 \%$ agarose gel at $75 \mathrm{~V}$ for $35 \mathrm{~min}$ and were visualized after stained with ethidium bromide (EtBr). After electrophoresis, DNA results were visualized via gel documentation (gel doc) to trace DNA fragment migration using a UV transilluminator.

\section{Statistical analysis}

The Quantum GIS (Arc GIS 10.6) was used to present spatial and geographic distribution of rodents trapping sites, and the bordering of Setif with epidemiological foci of ZCL. To study the link between climatic variables (temperature and rainfall), the cutaneous leishmaniasis and Meriones captured in Setif Province, we used the Excel stat 2014.5.03 for the Principal Component Analysis (PCA).

\section{RESULTS AND DISCUSSION}

\section{Cutaneous leishmaniasis incidence}

In the last decade (2008-2018), 676 cases of human cutaneous leishmaniasis were registered in the Province of Setif. The zoonotic CL disease was spread in most parts of the Setif Province with a higher prevalence in the southern zone, where $609(90.08 \%)$ cases were recorded during this period, $55(8.13 \%)$ cases in the central zone and only 12 $(1.77 \%)$ cases in the northern zone. This may be due to climatic factors and rodents as a reservoir host existed in the Province of Setif. Addedly, the migrations of infected Meriones shawi population can catalyze a pandemic's spread from endemic regions to non-endemic regions.

Regarding the ZCL annual distribution in Province of Setif from 2008 to 2018 , we have noted a $600 \%$ increase (from 30 cases in 2008 to over 140 cases in 2018). The highest yearly recorded cases occurred in 2010, 2011, and 2018 with 123, 116, and 139 cases, respectively. The annual incidence rate in Province of Setif was 9.46 cases per 100,000 inhabitants in 2010, 8.85cases in 2011 and 9.34 cases in 2018. The evolution of ZCL incidence in Setif between 2008 and 2014 is similar to the country incidence and from 2014 to 2018 became inversely proportional. The Evolution of the incidence of Human ZCL in Algeria from 2008 to 2018, show that several peaks have occurred in 2009, 2011, and 2017, however, in Province of Setif higher the incidence rate was 9.46 cases per 100,000 inhabitants in 2010, 8.85cases in 2011 and 9.34 cases in 2018 (Figure 2).

Concerning the gender of affected patients, the males are the most affected with $451(66.71 \%)$, however, 225 $(33.28 \%)$ females were registered. Zoonotic cutaneous leishmaniasis affects all ages from children to the elderly. Concerning the age distribution of ZCL, Figure 3 shows that young adults [16-25] and adults [26-50] are the most affected. 


\section{Relationship between ZCL and rainfall}

The principal component analysis applied on the variables annual rainfall and the cases of the LCZ recorded during the period 2008-2018, gives information on the relationship that may exist between the two variables. Indeed we notice that factor 1 and factor 2 contain $100 \%$ of the inertia of the variation. Bartlett's test of sphericity informs the absence of correlation between the variables (Pvalue=0.45). We also note that the number of cases of the LCZ and rainfall are negatively correlated with respect to axis 1 , which contains $62.75 \%$ of the inertia (Figure 4). Rainfall is an important factor in the activity of the reservoir host and vector, but the occurrence of LCZ depends on other factors (Ramezankhani et al.2017). Negative association was demonstrated between rainfall and ZCL incidence, where no significant relationship was found between the annual mean rainfall and CL incidence, consistent with previous work in Nikonahad et al. (2017). The effect of rainfall was found to be significant $\left(\mathrm{P}_{\text {value }}=0.45\right)$. Our findings are quite convincing with those obtained from other Ramezankhani et al. (2018) studies, where rainfall exerted inverse effects on ZCL. Other results were also reported by Ghatee et al. (Ghatee et al. 2018). Hence, Zoonotic CL is an emerging disease linked to the affected environment and climatic factors (Nikonahad et al. 2017; Mohammadbeigi et al. 2021). Hence, it can be reasonably concluded that the permanence of endemicity depends generally on the climatic factors, that CL is more prevalent in dry and semidry areas with low precipitation (Mokhtari et al. 2016). Also, the appearance of the ZCL depends on other factors (Benelmouffok et al. 2017; Inceboz 2019).

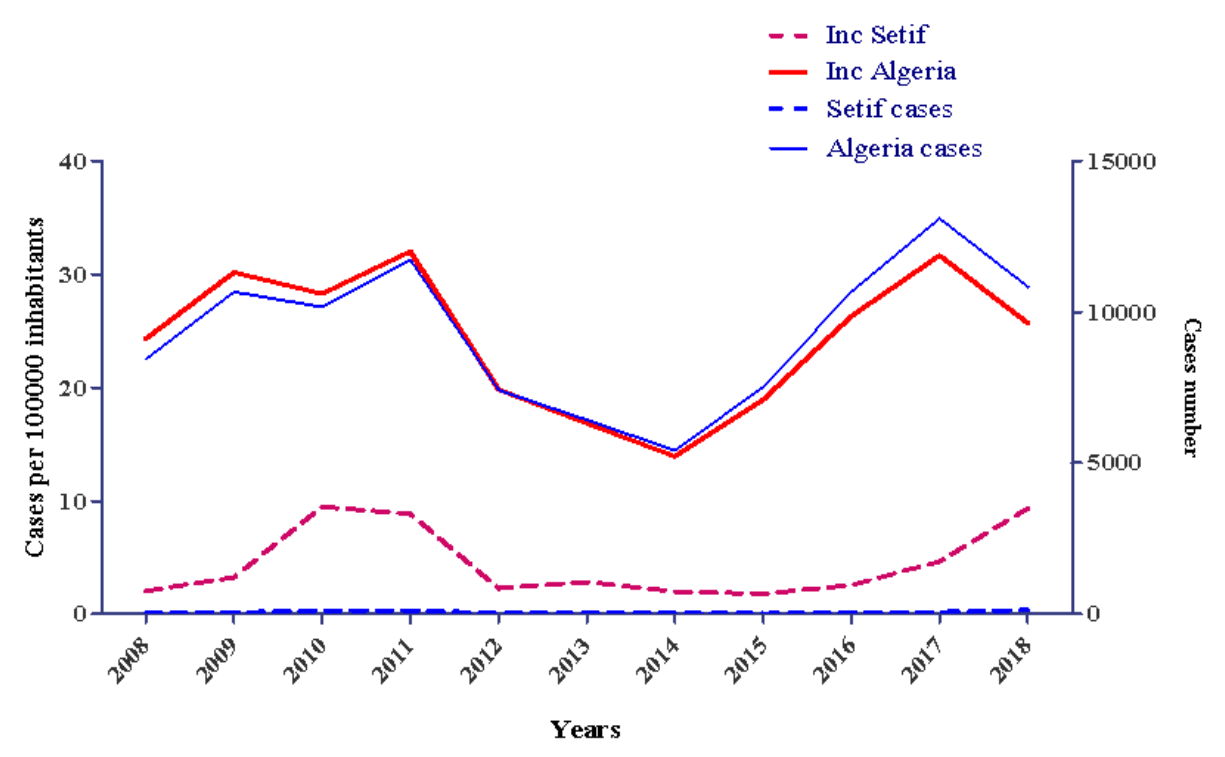

Figure 2. Evolution of the case number and the incidence of Human ZCL in Algeria and the Province of Setif from 2008 to 2018.

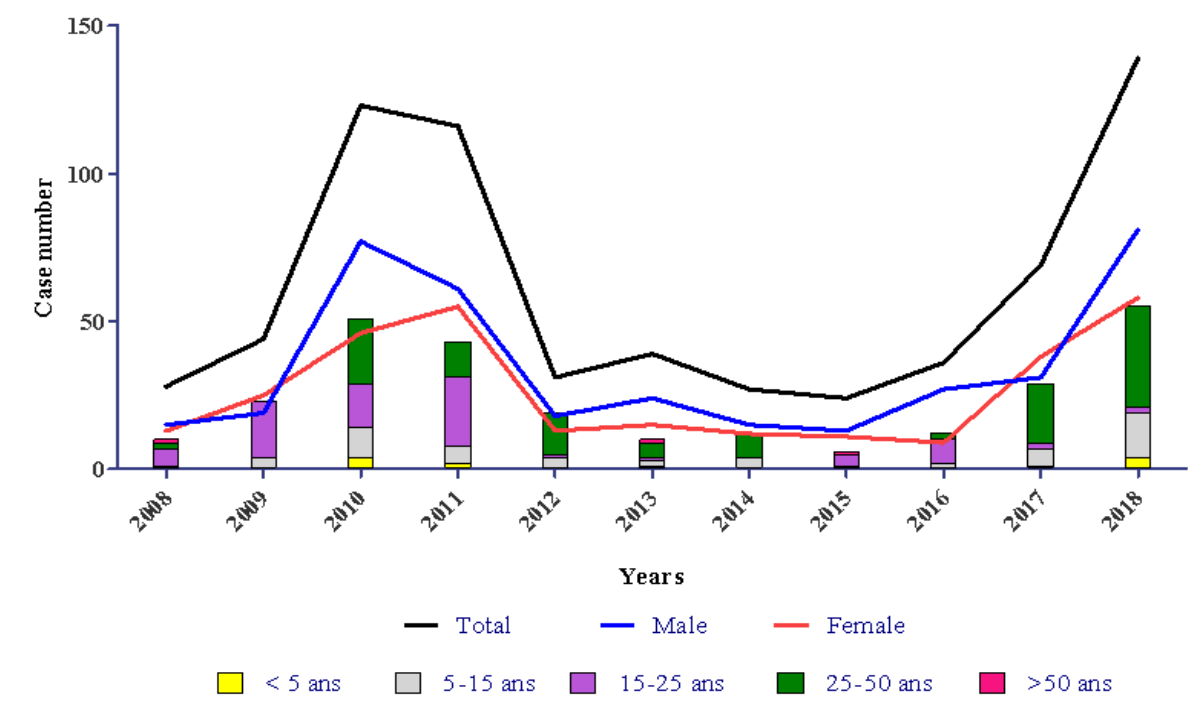

Figure 3. Number of ZCL cases reported in Setif by gender and age, during 2008-2018 period 
Biplot (axes F1 et F2 : 100,00 \%)

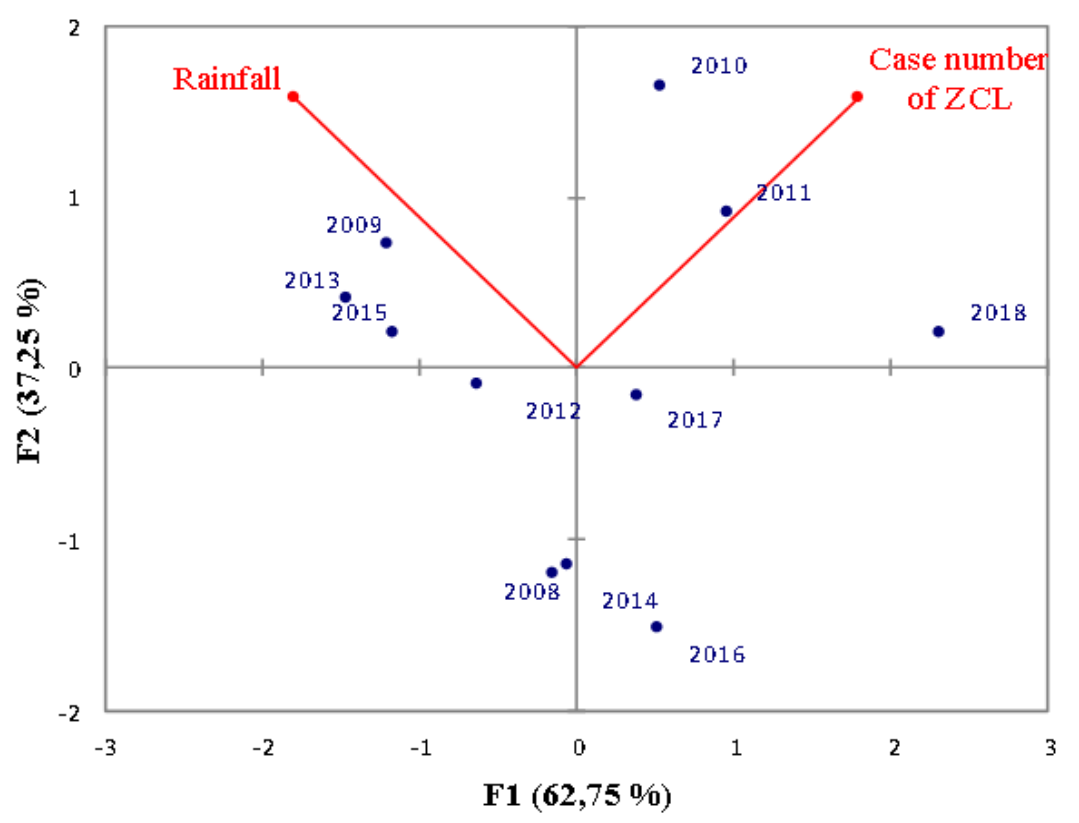

Figure 4. Principal component analysis of variation of cases number and rainfall among ten years in Setif Province (2008 to 2018) The number of cases of ZCL and rainfall are negatively correlated

\section{Rodent identification and dispersion}

For determination of reservoir hosts of the disease, altogether 112 rodents were captured and identified. They were $M$. shawi (86/112) (76.78\%), Psammomys obesus (3/112) (2.67\%), Mus musculus (5/112) (4.46\%), Ratus ratus (12/112) (10.71\%), Gerbilus gerbilus (4/112) $(3.57$ $\%)$ and Duprasi sp. (2/112) (1.78\%). M. shawi has been the most abundant species. The lowest number was found in the north with five specimens $(5.81 \%)$, whereas, the highest number of 50 specimens $(58.13 \%)$ was observed in the south (Table 2). Also, $47(54.65 \%)$ male and 39 (45.34 $\%)$ female of this species were registered (Table 4). $P$. obesus was nearly absent. It prefers presaharienne area according to Boubekri and Gernigon 2013, while a semiarid climate characterizes the Province of Setif.

Although all collected animals were examined by direct examen and PCR for parasite, only $M$. shawi were found to be infected by $L$. major. Thus, the results showed a remarkable prevalence of Leishmania in Meriones. These findings are also consistent with the findings of other studies carried out in Iran by Foroutane et al. (2017) and the largest number of infection cases (32/86) was found (Table 3). Smears were taken from 32 specimens that showed lesions. Cutaneous Leishmaniasis lesions of ears and noses were found mainly on 28 specimens. Although Leishmania amastigotes were found after microscopic observation in $87.5 \%$ of smear. These findings are also consistent with the findings of other studies in Algeria, where, the first $M$. shawi was found to be naturally infested by $L$. major in M'sila outbreak and the second, M. shawi Ksar chellala outbreak (Belazzoug 1982; Belazzoug 1986).

The most important infected animals were reported in 10 females and 22 males (an overall prevalence of 37\%) (Table 4). Similarly, the treatment of specimens captured in two years (Figure 5) confirmed that areas located in center $(43.75 \%)$ and south $(53.12 \%)$ of Setif Province had the highest potential to harbor this species than northern area $(3.12 \%)$. The all infested individuals came from the sites of Beni Aziz (1/32), Guellal (2/32), Eulma (9/32), Bir Haddada (3/32), Hamma (5/32), Rasfa (4/32) and Boutaleb $(8 / 32)$; however non-infested specimens were found in Aiin Kbira, Bougaa, and Guedjel (Table 3). The prevalence of $L$. major infection in Meriones living in the south and center of Setif Province (Table 3) can be explained by the capacity of these rodents to harbor the parasite as good reservoir hosts. Thus, this area is probably considered as the best ecological niche, where the risk of transmission was high. Addedly, the highest reported CL cases incidence were noticed in sites with an altitude lower than $800 \mathrm{~m}$, on the other hand, the lowest number of cases were found in areas with an altitude of over $900 \mathrm{~m}$. Our result is in line with Research by Ramezankhani et al. (2018), showing that $\mathrm{CL}$ is more prevalent in areas with low altitude. Also, the migrations of infected $M$. shawi population can catalyze a pandemic's spread from endemic regions to non-endemic regions. 
Table 2. Number of cases of zoonotic cutaneous leishmaniasis reported in Setif during 2008-2018 period
Table 4. Meriones shawi captured and specimens infected with leishmania by gender, during 2017-2018 period

\begin{tabular}{lcc}
\hline Region & ZCL Number & Percentage (\%) \\
\hline North & 12 & 1.77 \\
Center & 55 & 8.13 \\
South & 609 & 90.08 \\
\hline
\end{tabular}

\begin{tabular}{ccccc}
\hline \multirow{2}{*}{ Region } & \multicolumn{2}{c}{$\begin{array}{c}\text { Gender of Meriones } \\
\text { shawi captured }\end{array}$} & \multicolumn{2}{c}{$\begin{array}{c}\text { Gender of Meriones } \\
\text { shawi infected }\end{array}$} \\
\cline { 2 - 5 } & M & F & M & F \\
\hline North & 01 & 03 & 00 & 00 \\
Center & 19 & 15 & 10 & 04 \\
South & 27 & 21 & 12 & 06 \\
Total & 47 & 39 & 22 & 10 \\
\hline
\end{tabular}

Table 3. Number of Meriones shawi captured and specimens infected with leishmania during 2017-2018 period

\begin{tabular}{|c|c|c|c|c|c|}
\hline \multicolumn{2}{|c|}{ Region } & \multirow{2}{*}{$\begin{array}{c}\begin{array}{c}\text { Number of specimens } \\
\text { captured }\end{array} \\
02\end{array}$} & \multirow{2}{*}{$\begin{array}{c}\text { Percentage }(\%) \\
5.81\end{array}$} & \multirow{2}{*}{$\begin{array}{c}\begin{array}{c}\text { Number of specimens } \\
\text { infected }\end{array} \\
01\end{array}$} & \multirow{2}{*}{$\begin{array}{c}\text { Percentage }(\%) \\
3.12\end{array}$} \\
\hline North & Beni Aziz & & & & \\
\hline & Ain Kbira & 01 & & 00 & \\
\hline & Bougaa & 02 & & 00 & \\
\hline \multirow[t]{4}{*}{ Center } & Guidjel & 05 & 36.04 & 00 & 43.75 \\
\hline & Guellal & 05 & & 02 & \\
\hline & Bir Haddada & 08 & & 03 & \\
\hline & El Eulma & 13 & & 09 & \\
\hline \multirow[t]{3}{*}{ South } & Rasfa & 09 & 58.13 & 04 & 53.12 \\
\hline & Hamma & 19 & & 05 & \\
\hline & Boutaleb & 22 & & 08 & \\
\hline
\end{tabular}

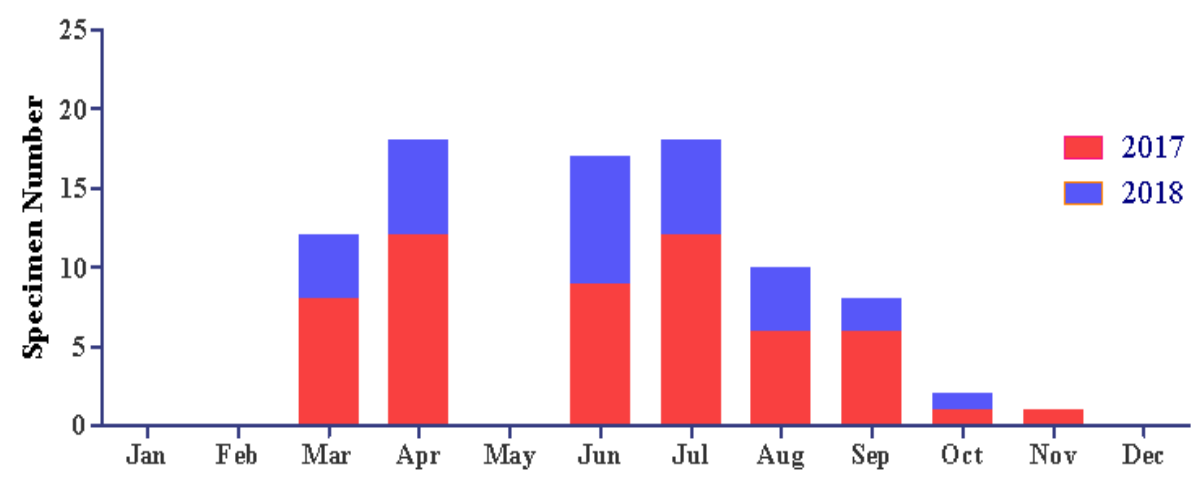

\section{Month}

Figure 5. Number of Meriones shawi specimens captured during 2017-18 period

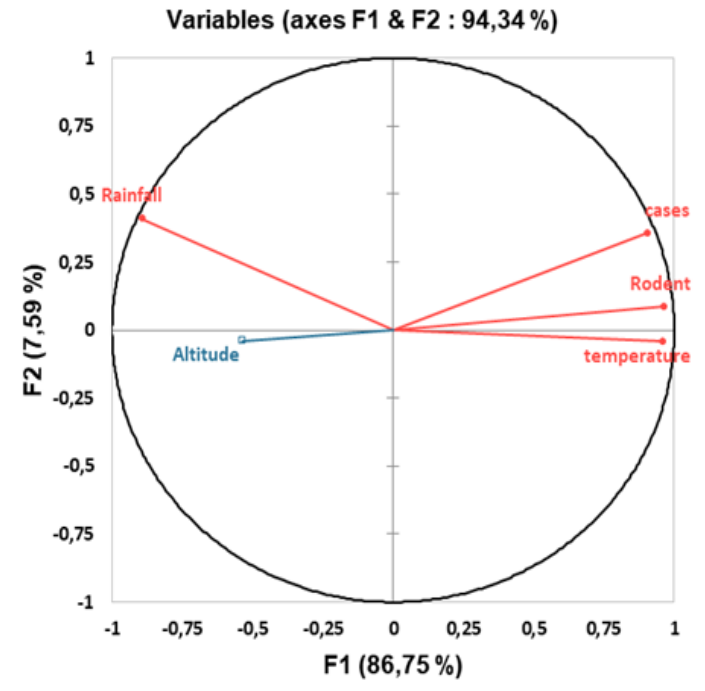

A

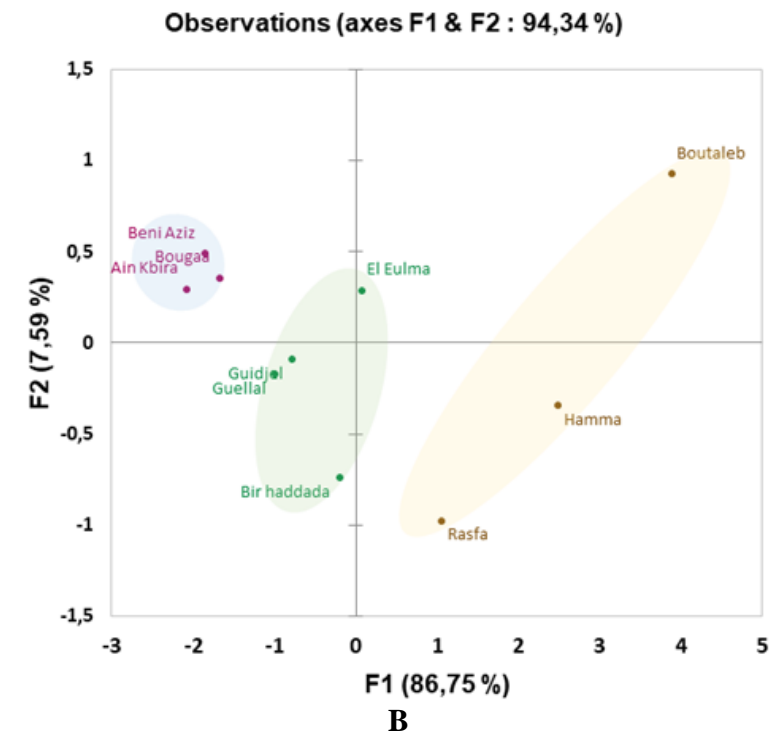

B

Figure 6. Principal component analysis of variation of cases number, temperature and rainfall among the specimens captured three regions of Setif Province. A. Variables, B. Observations and regions clusters (yellow is south, green is center and blue is north) 
To study Rodent dispersion factors in Setif Province, we applied the principal component analysis on the variables annual rainfall and temperature, cases of the LCZ, rodent number recorded during the period 2017-2018 in 10 sites of rodent catching in Setif Province, to identify the information on the relationship that may exist between these variables. Indeed we notice that factor 1 and factor 2 contain $94,34 \%$ of the inertia of the variation. Bartlett's test of sphericity informs the correlation between the variables (P-value < 0.0001). The Pearson Matrices of correlation showed a positive link between Rodent and ZCL cases $(p=0.861)$, Rodent and Temperature $(p=0.929)$, ZCL cases and Temperature $(p=0.809)$ (figure $6 B)$. We also note that the number of cases of the LCZ and specimens of Meriones captured and infected and Temperature are positively correlated to axis 1 , which contains $86.75 \%$ of the inertia (Figure 6.A).

Positive association was demonstrated between ZCL incidence in south and center areas of Setif Province and Meriones captured and infected, where a significant relationship was found, and this is consistent with previous work in previous study in Biskra by Guaouaoui et al. (2017). The activity of $M$. shawi in the southern areas of Setif is therefore probably due to several waves of rodent species migration from the south known endemic regions, such as Batna and M'Sila and conditioned by the climatic oscillations that caused the extension or retraction of the Sahara as reported by Belazzoug (1982); Belazzoug (1986) and more recently by Bounoua et al. (2013). Furthermore, Sedaghat and Salahi-Moghadam (2010); Gholamrezaei et al. (2016) noted that the distribution of rodents is due to the climatic shift. In addition, Boudrissa et al. (2012) showed the spread of cutaneous leishmaniasis from the arid areas to semi-arid areas of Algeria. Benelmouffok et al. (2017) mentioned that cereal-producing provinces were the most affected by ZCL.

Thus, the development of agriculture in the region increases the risk of ZCL transmission, through the agricultural products, which attracts new Meriones to build typically their perfect habitats and establish optimal conditions for transmission of this zoonosis between individual hosts of the same species and via $M$. shawi host species to humans. The Altitude was an additional variable studied by the PCA with a positive link with the rainfall $(\mathrm{p}=0,467)$. Our results were similar to those of Ramezankhani et al. (2018), where the highest CL cases incidence were found in sites with an altitude lower than $800 \mathrm{~m}$. Besides a small number of cases were found in regions with an altitude over $900 \mathrm{~m}$, and this may be due to the type of vector. Our results were in line with previous studies showing that CL is more prevalent in areas with low precipitation (Mokhtari et al. 2016).

To conclude, this research paper reported the presence of $M$. shawi as potential reservoirs of ZCL in Province of Setif. Our finding suggests that $M$. shawi is probably the principal reservoir host of ZCL and the only source of human infection in Province of Setif. This study, confirms that this Gerbilid plays a significant role in transmission of this zoonose and the incubation of L. major as a good and major reservoir host in the study area, since $P$. obesus was nearly absent. To establish an eco-epidemiological study in a new focus of ZCL, the reservoir host must be taken into consideration. The study findings can be therefore used in proper mapping for endemiological surveillance.

\section{ACKNOWLEDGEMENTS}

The author would like to thank the laboratory team at Institut Pasteur d'Algérie-IPA (Algeria), especially, Benikhlef Razika for the molecular part and Faculty of Science- Med BOUDIAF University -M'Sila (Algeria) researchers for their collaboration. The authors would like also to acknowledge the valuable rewriting and proofreading of OUENNAS Sara, the representative of TRANS-OFFICE (Translation Bureau, E-mail: transoffice2@gmail.com), which has improved the quality of this paper.

\section{REFERENCES}

Alvar J, Vélez ID , Bern C, Herrero M, Desjeux P, Cano J, Jannin J, Den Boer M. 2012. Leishmaniasis worldwide and global estimates of its incidence. PLoS ONE 7(5): e35671. DOI: 10.1371/journal.pone.0035671.

Aoun K, Bouratbine A. 2014. Cutaneous leishmaniasis in North Africa: A review. Parasite 21:14-23. DOI: 10.1051/parasite/2014014.

Boubekri A, Gernigon T. 2013. Seasonal influence on the reproductive biology of the sand rats from the Southwest of Algeria. Dynamics \& Biodiversity of the Terrestrial \& Aquatic Ecosystems; USTHB-FBS-4th International Congress of the Populations \& Animal Communities. Bechar, 19-21 November 2013, Algeria.

Barkatia S, Ndaoa M, Libmana M. 2019. Cutaneous leishmaniasis in the 21 st century: From the laboratory to the bedside. Curr Opin Infect Dis (32)5: 419-425. DOI: 10.1097/QCO.0000000000000579.

Belazzoug S. 1982. An epidemic of cutaneous leishmaniasis in the M'sila region (Algeria). Bull Soc Pathol Exot 75:497-504.

Belazzoug S. 1986. Discovery of a Meriones shawï (Rodent, gerbillid) naturally infested with Leishmania in the new outbreak of cutaneous leishmaniasis in Ksar chellala (Algeria). Bull Soc Pathol Exot 79:6303 .

Benelmouffok AB, Sellami M, Boughoufalah A. 2017. Cutaneous leishmaniasis in Algeria: Quadrennial assessment. Med Sante Trop 27(3): 310-314. DOI: $10.1684 / \mathrm{mst} .2017 .0703$.

Bernard J. 1977. Damage caused by the rodents Gerbillidae to agriculture in North Africa and the countries of the Middle East. FAO/WHO/EPPO Conference on Rodents of Agricultural and Public Health Concern. Geneva, Switzerland, 15-18 June 1976. DOI: 10.1111/j.1365-2338.1977.tb02729.x.

Boudrissa A, Cherif K, Kherrachi I, Benbetka S, Bouiba L, Boubidi SC, Benikhlef R, Arrar L, Hamrioui B, Harrat Z. 2012. Extension of Leishmania major to northern Algeria. Bull Soc Pathol Exot 105:305. DOI: 10.1007/s13149-011-0199-4.

Bounoua L, Kahime K, Houti L, Blakey T. 2013. Linking climate to incidence of zoonotic cutaneous leishmaniasis (L. major) in PreSaharan North Africa. Intl J Environ Res Public Health 10: 31733175. DOI: 10.3390/ijerph10083172.

de-Souza RAF, Andreoli RV, Kayano MT, Carvalho AL. 2015. American cutaneous leishmaniasis cases in the metropolitan region of Manaus, Brazil: Association with climate variables over time. Geospat Health 10: 40-47. DOI: $10.4081 / \mathrm{gh} .2015 .314$.

Derbali M, Chelbi I, Ahmed SBH, Zhioua E. 2012. Leishmania major Yakimoff et Schokhor, 1914 (Kinetoplastida: Trypanosomatidae) in Meriones shawi Duvernoy, 1842 (Rodentia: Gerbillidae): Persistence of the infection in Meriones and its infectivity for the Sandfly vector (Phlebotomus) Papatasi scopoli, 1786 (Diptera: Psychodidae). Bull Soc Pathol Exot 105(5): 399-402. DOI: 10.1007/s13149-012-0259-4.

Eddaikra N, Ait-Oudhia K, Kherrachi I, Oury B, Moulti-Mati F, Benikhlef R, Harrat1 Z, Sereno D. 2018. Antimony susceptibility of Leishmania 
isolates collected over a 30-year period in Algeria. PLoS Negl Trop Dis 12(3): e0006310. DOI: 10.1371/journal.pntd.0006310.

Etemad A. 1978. Mammals of Iran, Rodents and Identification Key. Vol. 1. Natural Resource Protection and HumanEnvironment Association Press, Tehran.

Foroutan M, Khademvatan S, Majidiani H, Khalkhali H, Hedayati-Rad F, Khashaveh S, Mohammadzadeh H. 2017. Prevalence of Leishmania species in rodents: A systematic review and meta-analysis in Iran. Acta Trop 172: 164-172. DOI: 10.1016/j.actatropica.2017.04.022.

Ghatee MA, Haghdoost AA, Kooreshnia F, Kanannejad Z, Parisaie Z, Karamian M, et al. 2018. Role of environmental, climatic risk factors and livestock animals on the occurrence of cutaneous leishmaniasis in newly emerging focus in Iran. J Infect Public Health 11: 425-433. DOI: $10.1016 /$ j.jiph.2017.12.004

Gholamrezaei M, Mohebali M, Hanafi-Bojd AA, Sedaghat MM, Shirzadi MR. 2016. Ecological niche modeling of main reservoir hosts of zoonotic cutaneous leishmaniasis in Iran. Acta Trop 160: 44-52. DOI: 10.1016/j.actatropica.2016.04.014

Guaouaoui R, Zeroual S, Boudjelida H. 2017. Association between climatic changes and leishmaniasis incidence in Biskra District, Algeria. J Entomol Zool Stud 5(6): 43-49.

Harrat Z, Pratlong F, Belazzoug S, Dereure J, Deniau M, Rioux JA, Dedet JP. 1996. Leishmania infantum and L. major in Algeria. Trans R Soc Trop Med Hyg 90(6): 625-629. DOI: 10.1016/s0035-9203(96)904101.

Inceboz T. 2019. Epidemiology and ecology of leishmaniasis. Current Topics In Neglected Tropical Diseases. IntechOpen, UK. DOI: 10.5772/intechopen.86359.

Izri MA, Belazzoug S, Pratlong F, Rioux JA. 1992. Isolation of Leishmania major from Phlebotomus papatasi in Biskra. The end of an ecoepidemiological saga. Ann Parasitol Hum Comp 67: 31-32. DOI: $10.1051 /$ parasite/199267131.

Mohammadbeigi A, Khazaei S, Heidari H, Asgarian A, Arsangjang S, Saghafipour A, Mohammadsalehi N, Ansari H. 2021. An investigation of the effects of environmental and ecologic factors on cutaneous leishmaniasis in the old world: A systematic review study. Rev Environ Health 36(1): 117-128. DOI:10.1515/reveh-2020-0066.

Mokhtari M, Miri M, Nikoonahad A, Jalilian A, Naserifar R, Ghaffari HR, Kazembeigi F. 2016. Cutaneous leishmaniasis prevalence and morbidity based on environmental factors in Ilam, Iran: Spatial analysis and land use regression models. Acta Trop 163: 90-97. DOI: 10.1016/j.actatropica.2016.08.002.

Nikonahad A, Khorshidi A, Ghaffari HR, Aval HE, Miri M, Amarloei A, Nourmoradi H, Mohammadi A. 2017. A time-series analysis of environmental and metrological factors impact on cutaneous leishmaniasis incidence in an endemic area of Dehloran, Iran. Environ Sci Pollut Res 24: 14117-14123. DOI: 10.1007/s11356-017-8962-0.

Pratlong, F., Dereure, J, Ravel C., Lami P., Balard Y, Serres G. 2009. Geographical distribution and epidemiological features of Old World cutaneous leishmaniasis foci, based on the isoenzyme analysis of 1048 strains. Trop. Med. Health 14: 1071-1085. DOI: DOI: 10.1111/j.1365-3156.2009.02336.x.

Ramezankhani R, Hosseini A, Sajjadi N, Khoshabi M, Ramezankhani A. 2017. Environmental risk factors for the incidence of cutaneous leishmaniasis in an endemic area of Iran: A GIS-based approach. Spat Spatio-temporal Epidemiol 21: 57-66. DOI: 10.1016/j.sste.2017.03.003.

Ramezankhani R, Sajjadi N, Nezakati Esmaeilzadeh R, Jozi SA, Shirzadi MR. 2018. Climate and environmental factors affecting the incidence of cutaneous leishmaniasis in Isfahan, Iran. Environ Sci Pollut Res Int 25: 11516-11526. DOI: $10.1007 / \mathrm{s} 11356-018-1340-8$.

Reithinger R, Dujardin JC, Louzir H, Pirmez C, Alexander B, Brooker S. 2007. Cutaneous leishmaniasis. Lancet Infect Dis 7: 581-596. DOI: 10.1016/S1473-3099(07)70209-8.

Samy AM, Annajar BB, Dokhan MR, Boussaa S, Peterson AT. 2016. Coarse-resolution ecology of etiological agent, vector, and reservoirs of zoonotic cutaneous leishmaniasis in Libya. PLoS Negl Trop Dis 10(2): e0004381. DOI: 10.1371/journal.pntd.0004381.

Schönian G, Nasereddin A, Dinse N et al. 2003. PCR diagnosis and characterization of Leishmania in local and imported clinical samples. Diagn Microbiol Infect Dis 47 (1): 349-358. DOI: 10.1016/s07328893(03)00093-2.

Sedaghat MM, Salahi-Moghadam A. 2010. Mapping the distribution of the important rodents' reservoir in Iran. Army Univ J 8: 210-223.

Seid A, Gadisa E, Tsegaw T, Abera A, Teshome A, Mulugeta A et al. 2014. Risk map for cutaneous leishmaniasis in Ethiopia based on environmental factors as revealed by geographical information systems and statistics. Geospat Health 8: 377-387. DOI: 10.4081/gh.2014.27.

Sergent ED, Sergent ÉtT, Parrot L, Donatien A, Beguet M. 1921. Transmission du clou de Biskra par le phlébotome (Phlebotomuspapatasi Scop.). CR Acad Sci 173: 1030.

Sidorova JV, Biderman BV, Nikulina EE, Sudarikov AB. 2012. A simple and efficient method for DNA extraction from skin and paraffinembedded tissues applicable to T-cell clonality assays. Exp Dermatol 21(1):57-60. DOI: 10.1111/j.1600-0625.2011.01375.x

Tabbabi A. 2019. Review of Leishmaniasis in the Middle East and North Africa. Afr Health Sci 19(1): 1329-1337. DOI: 10.4314/ahs.v19i1.4.

Teka O, Mensah GA, Holou R. 2002. Colonization of forage plots by rodent species in southern Benin: Case of the Samiondji breeding farm. Proceedings of the seminar-workshop on mammalogy and biodiversity, 30 October-18 November 2002, in: Société pour l'étude et la protection des mammifères, Abomey-Calavi 33-39.

WHO (World Health Organization). Leishmaniasis. 2019. Available from: https://www.who.int/news-room/fact-sheets/detail/leishmaniasis [Accessed 14 August 2019]. 